\title{
Performance Characteristics and Cost Optimization of Self-Compacting Concrete with Industrial Waste Additives to be Used in Agricultural Buildings
}

\begin{tabular}{|c|c|}
\hline \multicolumn{2}{|c|}{$\begin{array}{l}\text { Selçuk Memiş } \mathbf{1 , a , *} \\
{ }^{1} \text { Depertment of Çivil Engineering, Engineering Faculty, Kastamonu University, } 37150 \text { Kastamonu, Turkey } \\
{ }^{*} \text { Corresponding author }\end{array}$} \\
\hline ARTICLE INFO & A B S T R A C T \\
\hline $\begin{array}{l}\text { Keywords: } \\
\text { Fly ash } \\
\text { Chemical admixture } \\
\text { Marble powder } \\
\text { SCC } \\
\text { Fresh concrete }\end{array}$ & $\begin{array}{l}\text { Self-Compacting Concrete (SCC) is a building material that has gained importance recently because } \\
\text { it can easily and spontaneously settle in high buildings, where pouring conditions with frequent } \\
\text { reinforcement are difficult. Agricultural structures, on the other hand, are structures that involve many } \\
\text { units such as plant and animal barns, storage buildings and residences, and require care in their design } \\
\text { and construction. In this study prepared for this purpose, it is used in concrete by replacing marble } \\
\text { dust and fly ash with cement in concrete that will be used in agricultural structures. The main factor } \\
\text { in these studies is to obtain information about the behavior of KYB with marble powder and fly ash, } \\
\text { its fresh properties as well as its effect on durability, as well as to calculate the cost of marble powders } \\
\text { in SCC with superplasticizers and similar chemical additives. Within the scope of the study, different } \\
\text { ratios of marble powder (MP) and fly ash (FA) mixtures were created instead of OPC } 32.5 \text { and OPC } \\
42.5 .100 \mathrm{~mm} \text { cubic samples were prepared with the prepared mixtures and some of the physical } \\
\text { properties of these samples were determined in 3th, 7th and } 28 \text { th days. Samples were compared with } \\
\text { SCC concrete values with traditionally produced references. As a result, it has been determined that } \\
\text { the contribution of fly ash to SCC is more effective than the contribution of waste marble powder and } \\
\text { can be used as powder material. In terms of cost, it has been observed that it will provide advantages } \\
\text { in agricultural structures thanks to the high strengths obtained. }\end{array}$ \\
\hline
\end{tabular}

Türk Tarım - Gıda Bilim ve Teknoloji Dergisi, 9(1): 89-97, 2021

\section{Tarımsal Yapılarda Kullanılacak Endüstriyel Atık Katkılı Kendiliğinden Yerleşen Betonların Performans Özellikleri ve Maliyet Optimizasyonu}

\begin{tabular}{|c|c|}
\hline M A K A L E B İ L G İ S İ & Ö Z \\
\hline $\begin{array}{l}\text { Anahtar Kelimeler: } \\
\text { Uçucu kül } \\
\text { Kimyasal katkı } \\
\text { Mermer tozu } \\
\text { KYB } \\
\text { İşlenebilirlik }\end{array}$ & $\begin{array}{l}\text { Kendiliğinden Yerleşen Beton (KYB) sık donatıya sahip döküm koşullarının zor olduğu yerlerde, } \\
\text { yüksek binalarda kolay ve kendiliğinden yerleşebilmesi nedeniyle son zamanlarda önem kazanmış bir } \\
\text { yapı malzemesidir. Tarımsal yapılar ise bitki ve hayvansal üretim yapıları, depolama yapıları ve } \\
\text { konutlar gibi birçok birimi bünyesinde barındıran, projelendirilmesi ve yapımında özen gerektiren } \\
\text { yapılardır. Bu amaç kapsamında hazırlanan bu çalışmada tarımsal yapılarda kullanılacak betonlarda } \\
\text { mermer tozu ve uçucu külü çimento ile yer değiştirerek beton içerisinde kullanılmaktır. Bu } \\
\text { çalışmalarda temel unsur KYB'nin mermer tozu ve uçucu kül ile davranışı ve taze özelliklerin yanı } \\
\text { sıra dayanıklılık üzerindeki etkisi hakkında bilgi edinilmesi ve ayrıca KYB'deki mermer tozlarının } \\
\text { süper akışkanlaştırıcılar ve bunun gibi kimyasal katk1 maddeleri ile uyumluluğunun araştırılarak, } \\
\text { maliyetinin çıkartılmasıdır. Çalışma kapsamında PÇ 32,5 ve PÇ 42,5 yerine farklı oranlarda mermer } \\
\text { tozu ve uçucu kül karışımları oluşturulmuştur. Hazırlanan karışımlar ile } 100 \text { mm'lik küp numuneler } \\
\text { hazırlanmış ve bu numunelerin bazı fiziksel özellikleri ile birlikte 3th, 7th ve } 28 \text { th günlerde basıç } \\
\text { dayanımları belirlenmiştir. Örnekler, geleneksel olarak üretilen referans KYB beton değerleri ile } \\
\text { karşıllaştırılmıştır. Sonuç olarak, uçucu külün KYB'ye katkısının atık mermer tozunun katkısından } \\
\text { daha etkili olduğu ve toz malzeme olarak kullanılabileceği belirlenmiştir. Maliyet açısından ise elde } \\
\text { edilen yüksek dayanımlar sayesinde tarımsal yapılarda avantajlar sağlayacağ1 görülmüştur. }\end{array}$ \\
\hline
\end{tabular}




\section{Introduction}

Concrete is the most used building material in the world. The fact that the raw materials required in its production can be found in almost every region of the world and the production of an average of 10 billion tons of concrete annually in the world is an indication that it is one of the most popular construction materials. In addition, since its manufacture requires little energy, it has increased its popularity even more since it is important in sustainable construction. In addition to being a building element, concrete, which is also suitable for aesthetic appearance, in this respect; It has become the subject of many studies and practices that reduce costs, contribute to environmentalism, and improve quality (Kumanayake et al., 2018).

Today, as a result of researches and developments in concrete technology, it is seen that various concrete types such as High-Performance Concrete, Ultra High Strength Concrete, Light Concrete, Architectural Concrete and SelfCompacting Concrete (SCC) have been there. This issue has become interesting not only for engineers but also for ordinary people. In this respect, awareness of concrete species and more information should be taken into consideration. Regarding SCC, it can be said that it is one of the most recent contemporary concrete types. SCC, which does not need vibration, and thus, is easy to pour into difficult and narrow areas, is considered an innovative concrete mixture. It is commercially known by various names such as "Self-Consolidating Concrete", "SelfCompacting Concrete", "Self-Leveling Concrete" (Celik et al., 2015).

SCC is an innovative concrete for vibration-free placement and compression. With dense steel reinforcement, it can fill the mold completely with its flow under its own weight even in pressed and narrow areas and thus full compression can be achieved (Domone, 2006a, 2006b; Gaywala and Raijiwala 2011; Okamura and Ozowa, 1995; Okomura and Ouchi, 2003). The need for or less use of vibration causes a decrease in the time spent on construction. In addition to reducing workmanship by minimizing the cost of production, low noise and increased safety in the construction site are also seen as an advantage. In addition to the fluidity feature of SCC, it must also show a sufficient resistance to separation under its own weight (Zhao et al., 2015). The use of high powder content, super plasticizers and additives seems to be an ordinary solution to achieve high fluidity SCC without degradation during transport (Domone, 2007; Murthy et al., 2012). Materials with a high powder content replace the cement required in the mixture, and perform the same task, which is an economical advantage compared to conventional concrete (Zhao et al., 2015).

Thanks to these advantages provided by the use of SCC, it is widely applied in many areas such as tall buildings, bridges, tunnels and offshore structures (Ouchi, 2000). To provide high fluidity to the SCC and to prevent separation during transport and placement, a high proportion (450-600 kg.m $\mathrm{m}^{-3}$ ) ordinary portlant cement (OPC) should be used. For this reason, the cost of SCC is very high compared to conventional vibratory concrete. In addition to the disadvantage of being uneconomical, environmental impacts of OPC, which are used in large amounts in SCC, should be taken into consideration. OPC production leads to high $\mathrm{CO}_{2}$ emissions. This amount constitutes approximately $7 \%$ of the total global $\mathrm{CO}_{2}$ emission based on 2007 data. With the increase in demand for OPC worldwide, it is predicted that cement production will increase gradually and $\mathrm{CO}_{2}$ emission will correspond to approximately $10 \%$ of total global emission (Habert et al., 2011). Moreover, the OPC production process causes millions of tons of dust to be released into the atmosphere every year. It is stated that these powders cause respiratory diseases and a number of physical health problems in humans (Huntzinger and Eatmon, 2009; Sadrmomtazi et al., 2016).

As an alternative to solving these problems, SCC is to use industrial by-products, especially mineral additives, instead of OPC in its production. In other words, it is to use industrial side waste products as mineral additives in place of OPC in SCC (Ondova et al., 2011). Using mineral additives such as silica fume (SF), Fly ash (FA) Marble Powder (MP) can reduce the cost of materials and increase compatibility. Different studies have shown that natural pozzolan is widely used in many applications instead of OPC due to its advantageous properties such as cost reduction, reduced heat evolution, reduced permeability and increased chemical resistance (Dhiyaneshwaran et al., 2013; EFNARC, 2002; Shetty, 2012). For example, it is envisaged that preferring the use of FA instead of OPC will not only reduce the total material cost for SCC production, but will also provide significant benefits to the environment. In addition, MP, which is used as a mineral substitute for cement, is reported to increase some properties of fresh and hardened SCC (Belaidi et al., 2012; Tayeb et al., 2011).

Animal shelters include barns that house animals of different ages and physiological periods, rough and dense feed depots, milking units, buildings such as fertilizer and social facilities. Shelters in agricultural enterprises; These are animal production structures built to protect animals from the negative effects of external environmental conditions, to create a suitable production environment and to provide economy from time and labor (Okuroğlu and Delibaş, 1986; Karabacak and Topak, 2007; Memiş et al., 2017). Although the design of animal production structures varies considerably compared to other construction systems, the errors resulting from the design of their shelters cause the animals to survive in environmental conditions that are not suitable for their natural life conditions, and decrease their productivity and produce products below their capacity. Therefore, animal production structures are designed in accordance with the physical behavioral characteristics of animals (Usta, 2011; Memiş et al., 2017).

In Karaman (2005); It has been reported that the wastes from animal producing enterprises are stored and the waste leaks resulting from this storage cause water pollution. In addition, it has been observed that the first factor to be examined in terms of quantity and effects of this pollution is fertilizer. In addition, Karaman (2005) states that these wastes should be known in order to prevent adverse environmental conditions and create an unhealthy living environment, precautions to be taken, legal and technical 
standards, storage and projecting criteria. Soyer (2014), on the other hand, considering that the solid and liquid fertilizer, which is the main problem and produced in large quantities depending on the capacity, is collected or disposed unplanned, that the fertilizer tank should be made appropriately, reducing the odor effect in determining the structural properties of the fertilizers. He talked about the issues to be considered in the planning phase issues. As stated by Karaman (2005) and Soyer (2014) in our country, it is seen that the planning phase is generally emphasized. However, another issue to be considered in the planning of agricultural structures is to choose the concrete class and type according to the acidic environments that will arise from different factors such as fertilizer during both planning and construction (Memis et al., 2017).

One of the objectives pursued in the construction of agricultural structures is to increase production and increase its quality. Structures can only fulfill these functions if they are made in accordance with their technique using different materials. In order for the building to perform its function; the era should be made of advanced technical knowledge, technical equipment and materials. In addition, it must be robust and durable, as well as providing protection against unsuitable environmental conditions, unwanted living and inanimate. In addition to these, the most important factor is the construction of the building economically (Ekmekyapar, 1997).

Concrete used in agricultural structures; It is one of the most commonly used building materials such as manure pit and silage warehouse, especially in barn. In these environments, corrosion resistance caused by lactic and acetic acids formed by animal wastes is of great importance for floors, silos and animal shelters. (Belie et al., 2000, Wells and Melchers, 2014). However, concrete floors must be strong enough to support all loads of animals, people and equipment and the result of their dynamic actions. Different solutions are emphasized to produce high quality and durable concrete structure in reducing the effects of this situation. As per governmental environmental policies, other factors such as ammonia emissions from animal shelters have gained importance in recent years and they recommend special ground systems to reduce ammonia emissions. Among these measures, in terms of durability, the water / cement ratio of the concrete is not more than 0.45 and the cement content is not less than $350 \mathrm{~kg} \cdot \mathrm{m}^{-3}$ in the concrete coating, and the water absorption amount does not exceed $6 \%$ by mass (Belie et al., 2000).

In natural stone and marble processing plants, a large amount of MP is produced, which is more suitable in terms of environment and human health and is an industry byproduct. Within the scope of this study, it is designing SCC for SCC that can be used in agricultural enterprises and by adding mineral additives (MP, FA) as cement substitute material and making comparison of pressure resistance, water absorption ratio, unit volume weight and cost.

\section{Material and Methods}

\section{Materials}

In this study, CEM-I 32.5 R and CEM-I 42.5 R Portland cement which are in compliance with EN 197-1 standard were used. Sieve analysis as aggregate was used as aggregate of crushed stone and silica sand of limestone origin in accordance with TS 3530 EN 933-1. Considering the studies in Enbeya et al., (2019) instead of cement, the $15 \%$ ratio that would be most ideal was used at a fixed ratio for both FA and MP.

Fly ash (FA) was used as mineral additive in the concrete mixture and FA was obtained from Çatalağzı Thermal Power Plant. MP bags of 25 kilograms from the market were prepared ready and used in mixtures. Physical and chemical properties of cement and fly ash are given in Table 1. The polycarboxylate based superplasticizer (SP) was used in the mixture.

\section{Methods}

In the experimental study, three batches were produced, one for control at every cement type and three for each batch (Table 2). Fly ash and marble powder were substituted by $15 \%$ of cement. Aggregate and substitute materials were mixed dry in the concrete, then $1 / 3$ of the mixing water was added and stirring was continued. After mixing, cement and fly ash were added to the concrete until the homogenous mixture was maintained, and $1 / 3$ of the mixing water was added. Stirring was continued, the remaining mixture water added to the superplasticizer was added to the concrete for $3 \mathrm{~min}$. then the mixing was terminated. $100 \mathrm{~mm}$ cube specimens were placed in the sample containers for $3^{\text {th }}, 7^{\text {th }}$ and $28^{\text {th }}$ days compressive strength. The specimens were covered with an impermeable cover for 24 hours at $23 \pm 2{ }^{\circ} \mathrm{C}$ and the relative humidity of 55-60\%, then the samples taken from the sample cup were kept in lime saturated water at $20 \pm$ $2{ }^{\circ} \mathrm{C}$ until the test day. Compressive strenght according to TS 12390-3 was applied to the samples. Physical properties such as SCC unit volume weight are determined according to TS EN 772-4 (7) and water absorption values are determined according to TS EN 771-1 (8).

\section{Results}

\section{Fresh Property of SCC}

The following specifications are determined in accordance with EFNARC rules, which are accepted worldwide:

\section{Filling Capability:}

The ability of the SCC to flow and completely fill all gaps in the mold under its own weight. The ability to fill is generally measured by the sedimentation flow (Figure 1) and the cubes in which the concert is performed (Figure 2). According to the EFNARC manual, the Flow should be between 70 and $80 \mathrm{~cm}$.

\section{Hardened Properties of SCC}

Compressive strength is the average of at least three standard cured strength specimens made from the same concrete sample and tested at the same age. The vast majorities of cases strength requirements for concrete are at an age of $28^{\text {th }}$ days of curing. After $28^{\text {th }}$ days, the concrete cubes were examined for the purpose of their compressive strengths.

During the test comparison, the same size of cube $10 \times 10 \times 10 \mathrm{~cm}$ was made by Self Compacting concrete (SCC). In addition, test specimens of Self Compacting Concrete (SCC) cube were cured into water for $3^{\text {th }}, 7^{\text {th }}$ and $28^{\text {th }}$ days. The results of the mixtures are given in Table 4 . 


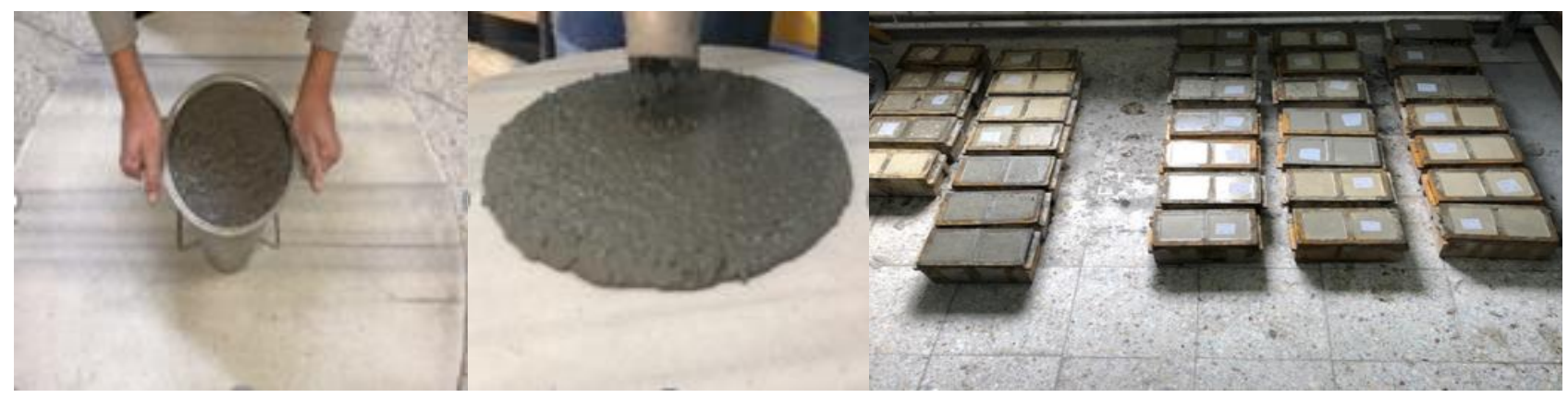

Figure 1. Slump flow

Figure 2. Mix groups
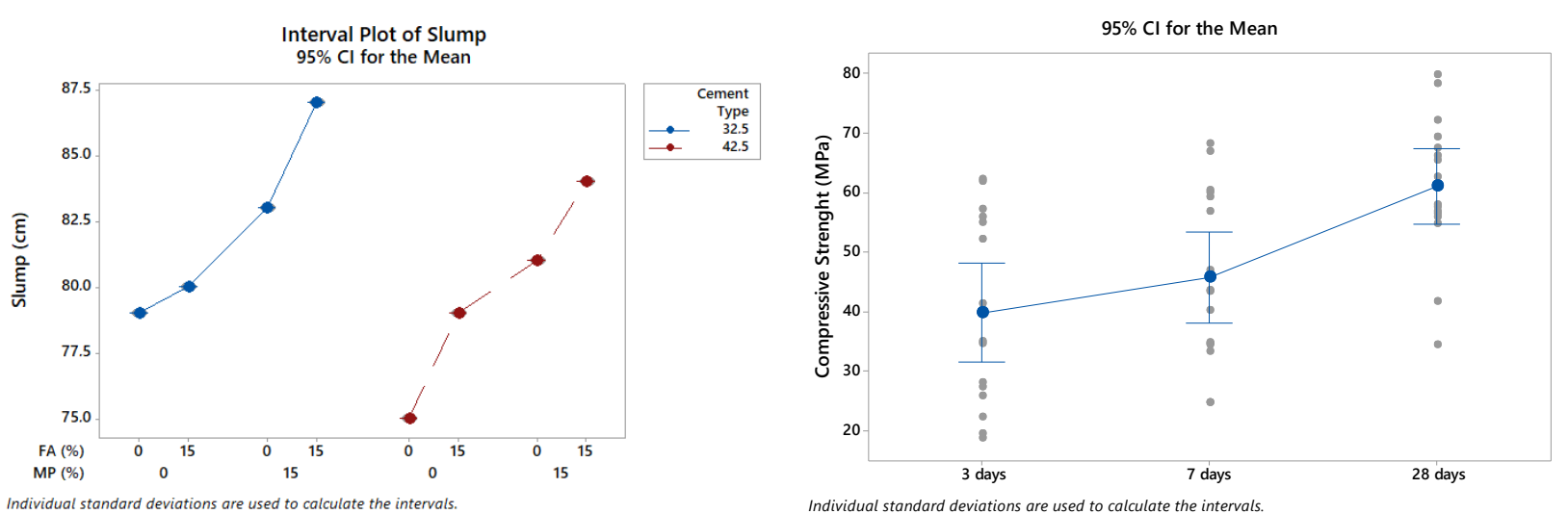

Figure 3. Change in flow diameter according to FA and MP Figure 4. Change of compressive strength of SCC over time

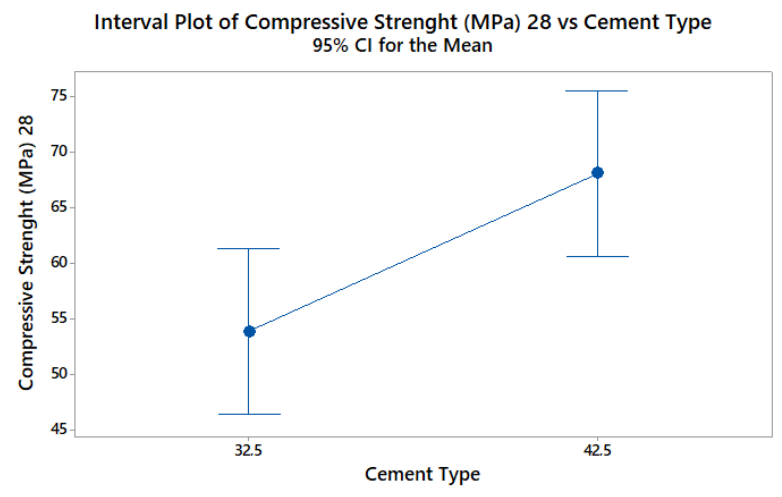

The pooled standard deviation is used to calculate the intervals.

As seen from Table 5, the compressive strenght values of the SCC varied between $18,56 \mathrm{MPa}$ and $62,14 \mathrm{MPa}$ for $3^{\text {th }}$ day, 24,66 MPa and $66,87 \mathrm{MPa}$ for $7^{\text {th }}$ day and 34,29 $\mathrm{MPa}$ and $78,35 \mathrm{MPa}$ for $28^{\text {th }}$ day. When the temporal changes of pressure strengths in SCCs were examined, there was an increase in strength in all groups for more than $100 \%$ strengths on the $7^{\text {th }}$ day. When compared with 28 day results, it was seen that there was an increase of 180$220 \%$ in reaching the final strength of the groups produced with OPC 32.5. Also, when this situation is analysed for OPC 42.5 , this increase ratio was between $117-146 \%$ and a lower increase compared to the other group. While the lowest increases in these changes were in the reference group for groups using OPC 32.5, FA $15 \%$ for groups using OPC 42.5 was used in the group (group 8). This can be explained by the fact that the pozzolanic effect for FA in high strength cements is more effective than MP in a short time. The unit weights and water absorptions ratio of produced SCC add the FA and MP were presented in Table 5, Figure 6 and Figure 7. As seen from Table 5, the unit weight values of the composites varied between 2,305 and $2,365 \mathrm{~kg} / \mathrm{dm}^{3}$ about the same in every group. And also, the water absorption values varied $\% 1,33$ between $\% 1,65$, too. The highest unit weight value was observed in reference mixture for OPC 32.5 and observed in In the group with $15 \%$ MP (Group 5) for OPC 42.5. 


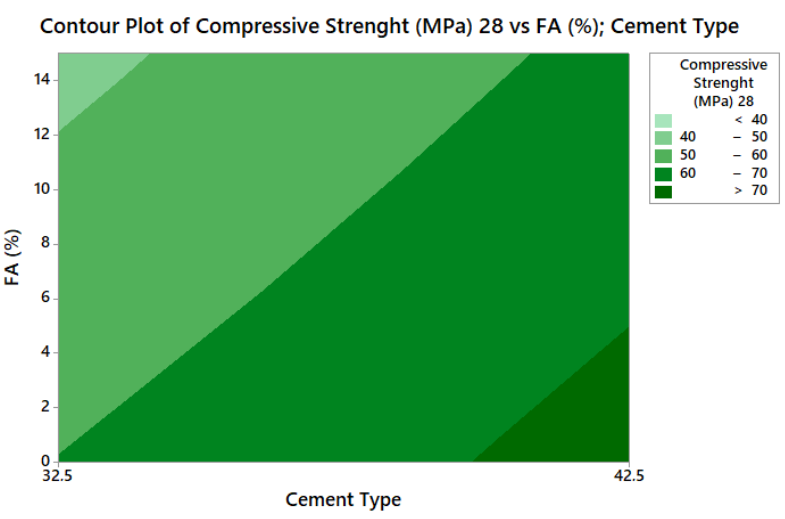

(a) Effect of FA

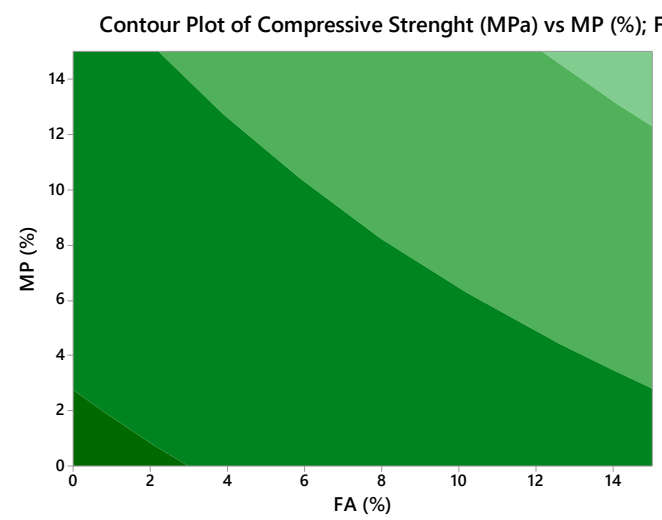

(c) General effect

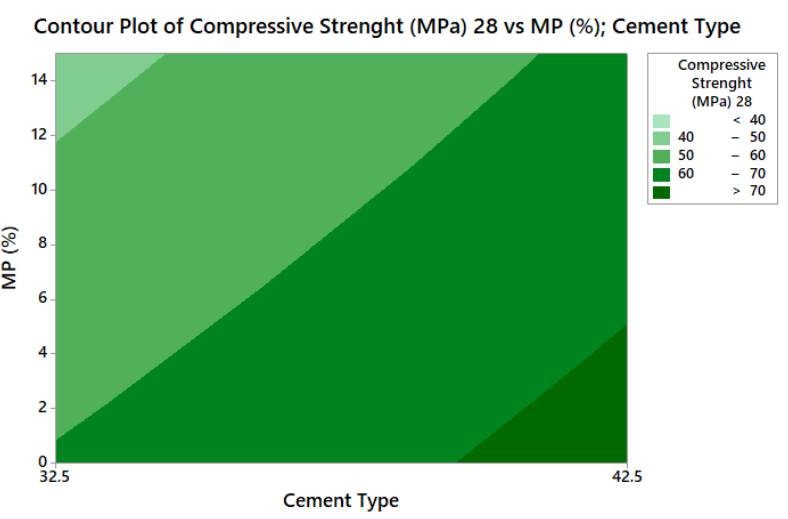

(b) Effect of MP

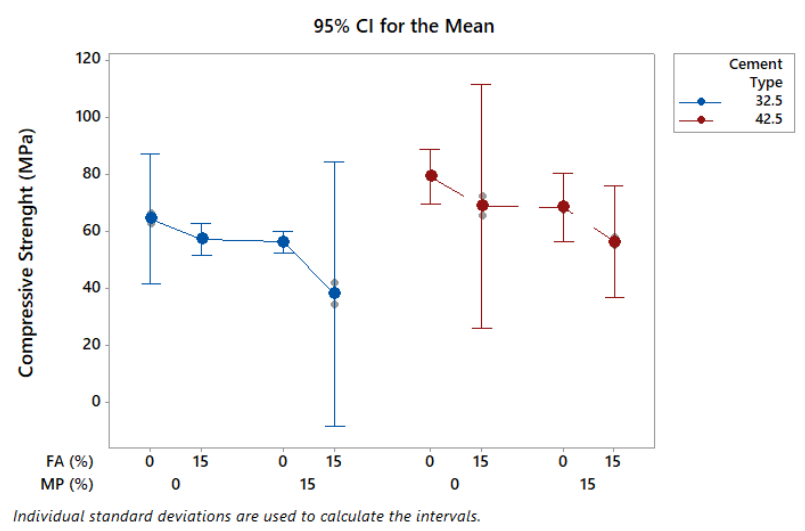

(d) Change by groups

Figure 6. Effect of additives on compressive strength

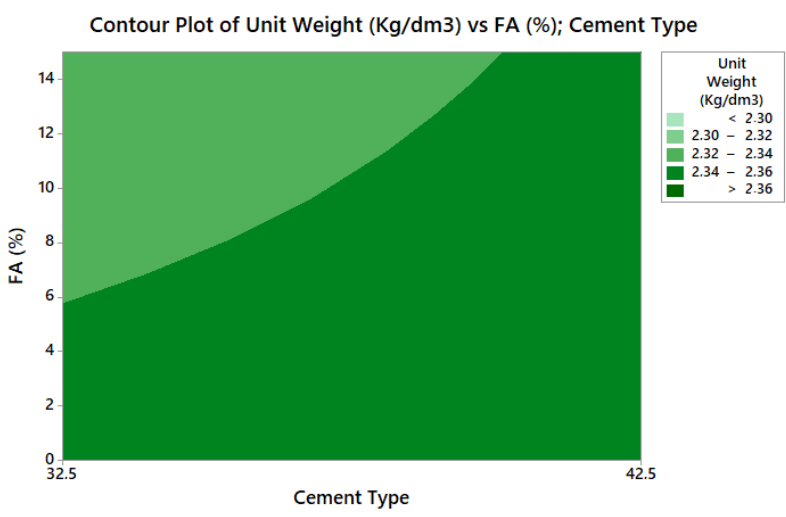

(a) Effect of FA

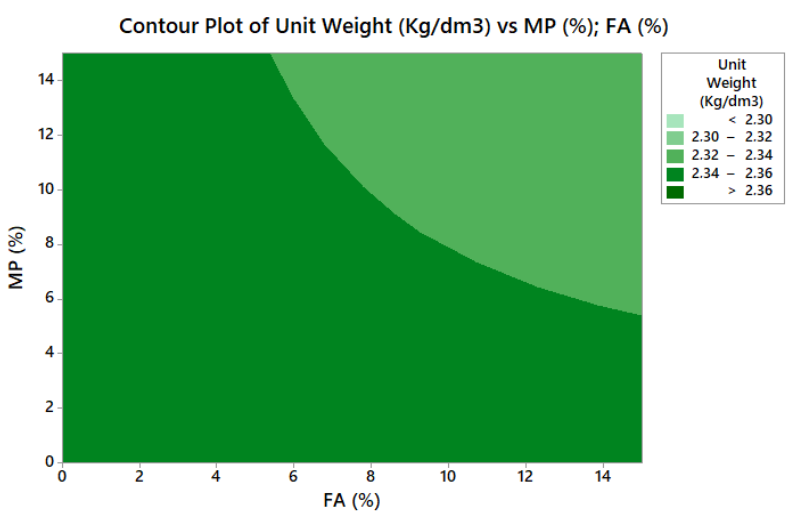

(c) General effect

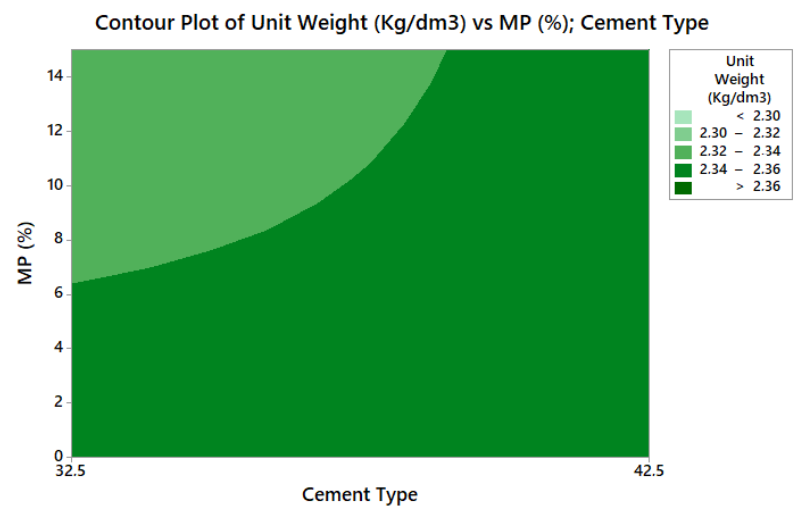

(b) Effect of MP

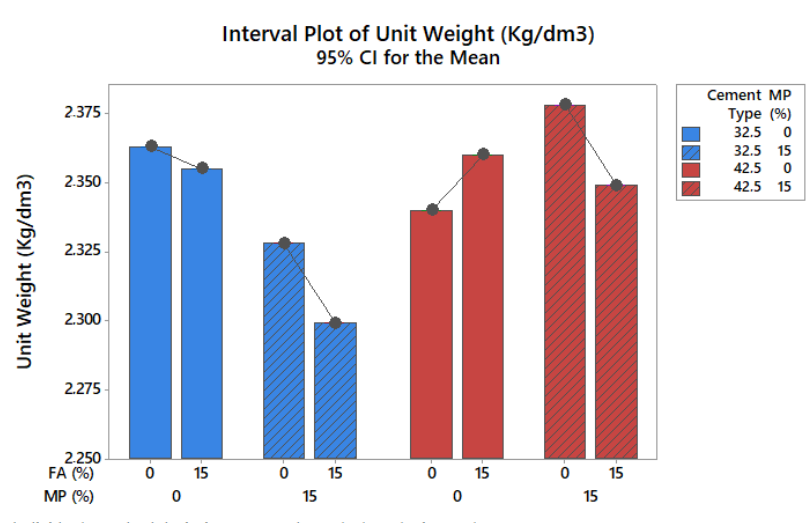

(d) Change by groups

Figure 7. Effect of additives on unit weight 


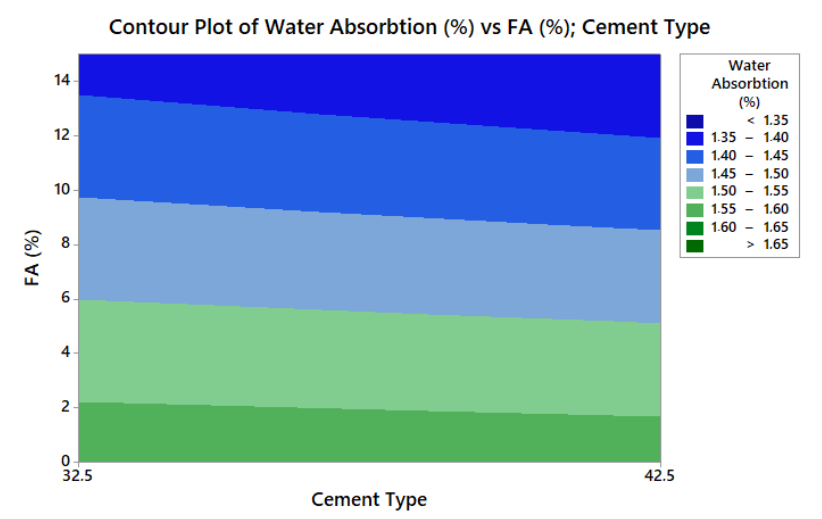

(a) Effect of FA

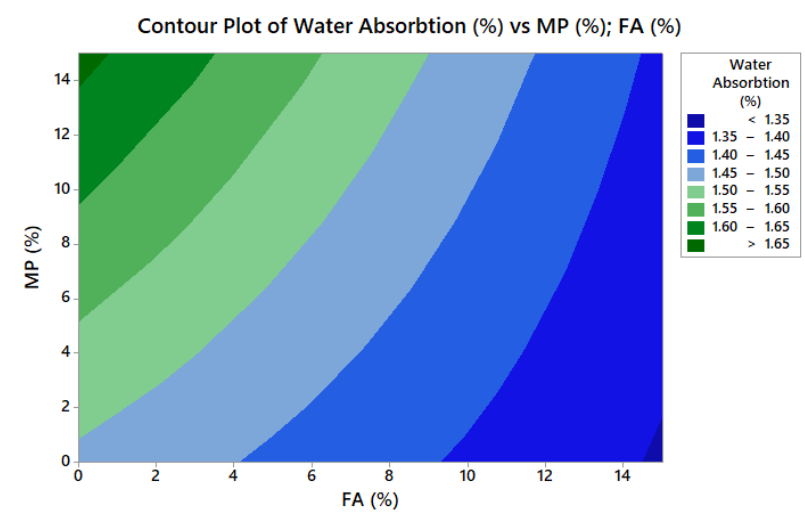

(c) General effect

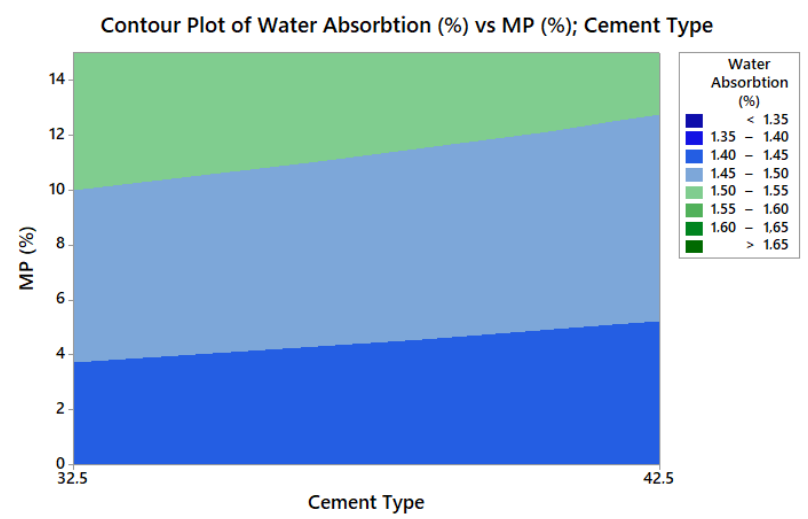

(b) Effect of MP

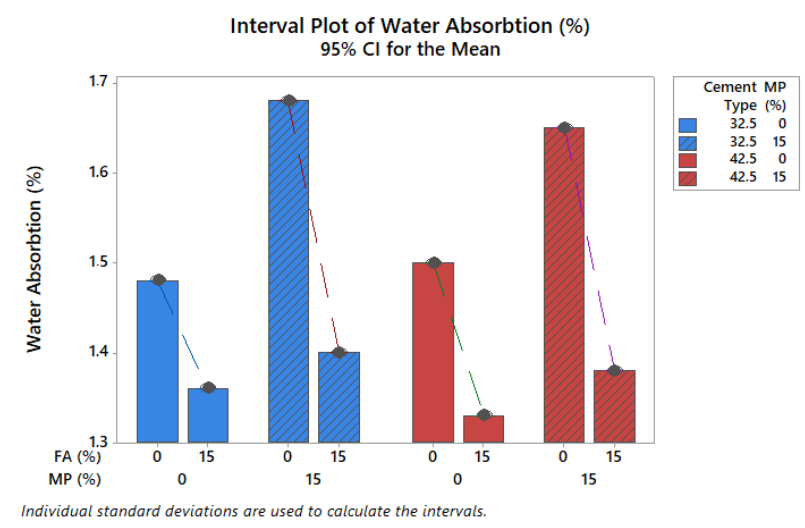

(d) Change by groups

Figure 8. Effect of additives on water absorption

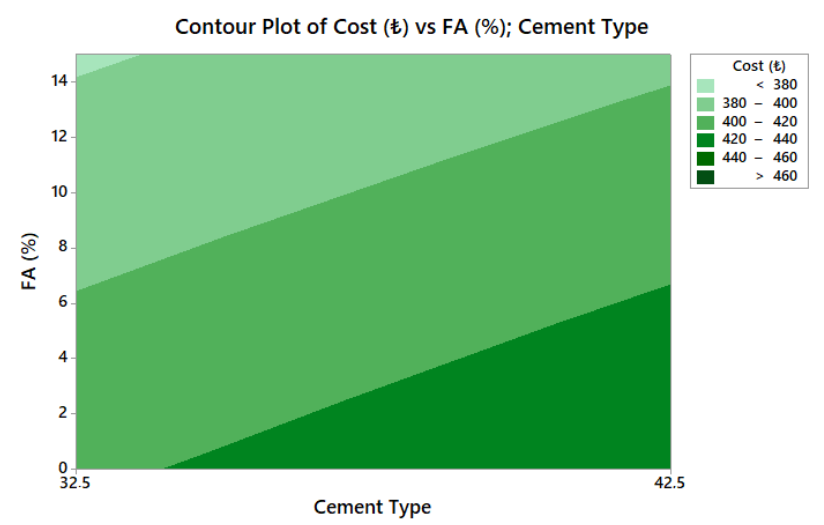

(a) Effect of FA

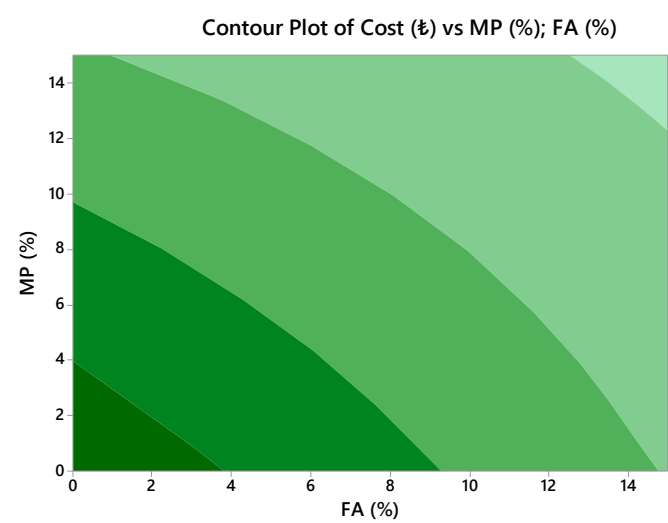

(c) General effect

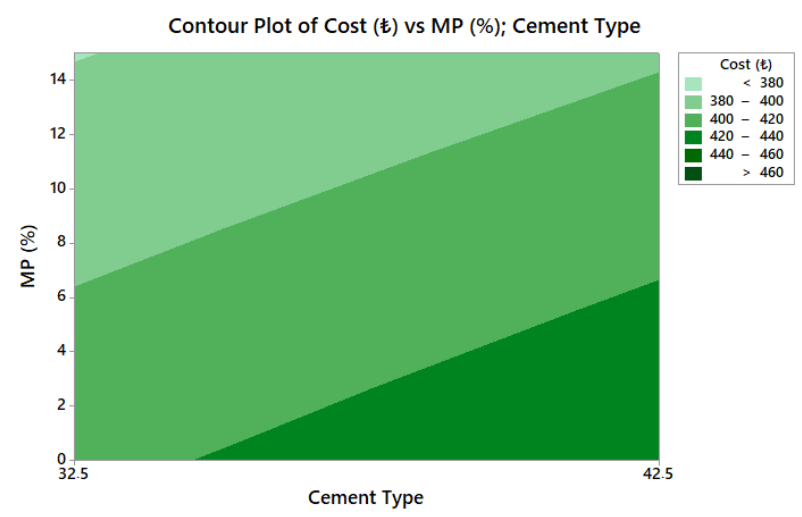

(b) Effect of MP

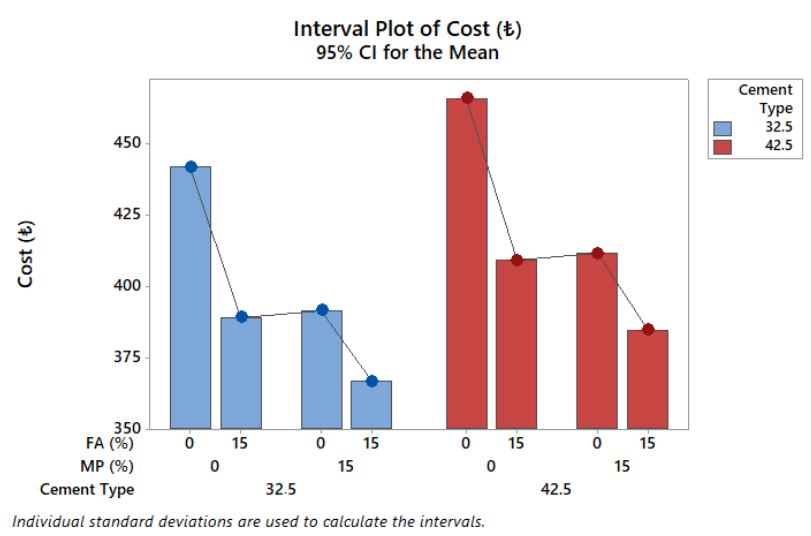

(d) Change by groups

Figure 9. Effect of additives on production cost 


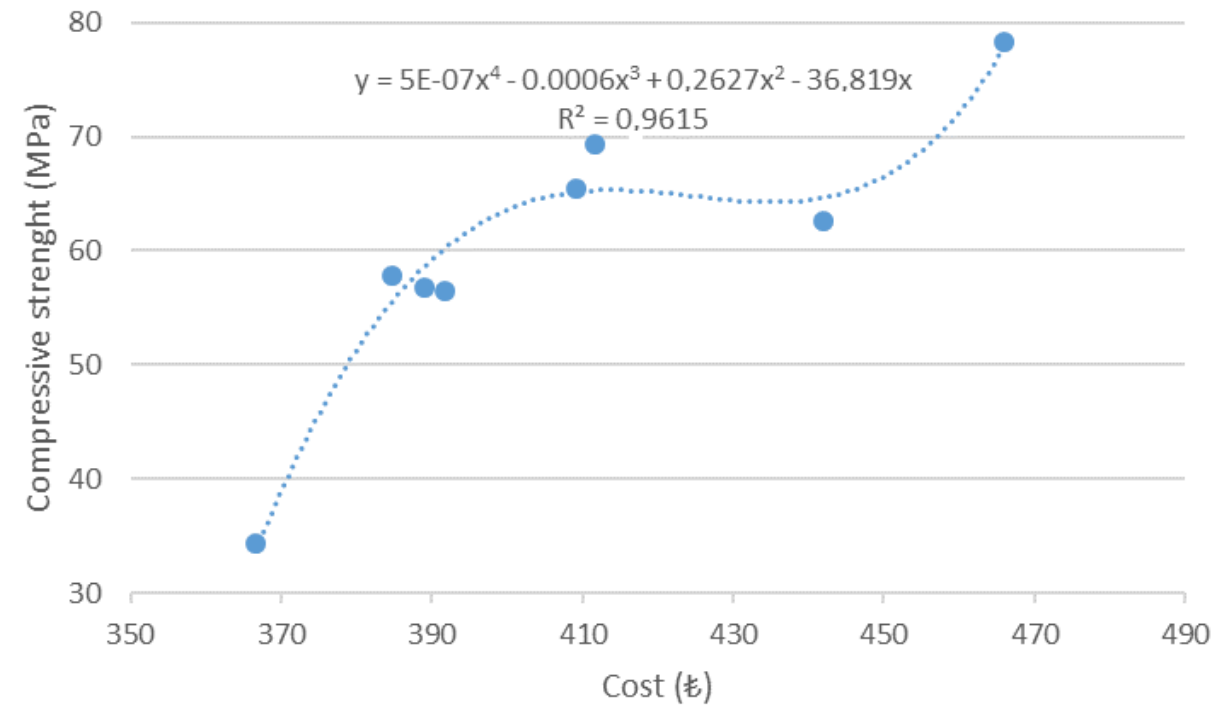

Figure 10. Production cost - compressive strenght relationship

Table 1. Chemical and physical properties of cement and fly ash

\begin{tabular}{l|cccc}
\hline \multicolumn{1}{c}{ Chemical Composition } & CEM II 32.5 & CEM I 42.5 R & FA & MP \\
\hline $\mathrm{CaO}$ & 56.50 & 63.48 & 1.73 & 51.80 \\
$\mathrm{SiO}_{2}$ & 18.44 & 20.35 & 55.73 & 4.67 \\
$\mathrm{Al}_{2} \mathrm{O}_{3}$ & 4.50 & 4.47 & 29.76 & - \\
$\mathrm{Fe}_{2} \mathrm{O}_{3}$ & 3.21 & 3.80 & 5.41 & 0.03 \\
$\mathrm{~K}_{2} \mathrm{O}$ & 0.72 & 0.19 & 3.11 & - \\
$\mathrm{MgO}$ & 2.57 & 1.02 & 3.30 & 0.40 \\
$\mathrm{SO}_{3}$ & 2.14 & 2.26 & 0.30 & \\
$\mathrm{Free} \mathrm{Lime}$ & 1.21 & 1.30 & - & \\
Loss of Glow & 2.42 & 2.63 & - & \\
Insoluble Residue & 0.67 & 0.65 & - & 2.63 \\
Spesific gravity $\left(\mathrm{g} / \mathrm{cm}^{3}\right)$ & 3.14 & 3.1 & 2.2 & - \\
Blaine $\left(\mathrm{cm}^{2} / \mathrm{gr}\right)$ & 4630 & 3200 & 3700 & \\
\hline
\end{tabular}

Table 2. Mix design $\left(\mathrm{kg} / \mathrm{m}^{3}\right)$

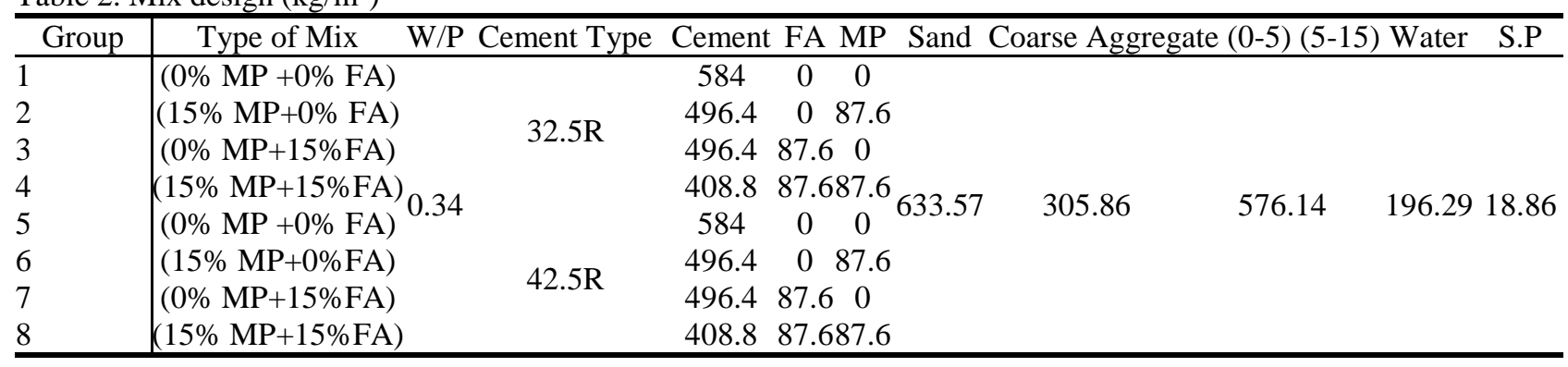

Table 3. Fresh properties of concrete with slump test

\begin{tabular}{l|cc}
\hline Group & Type of Mix & Slump $(\mathrm{cm}) 75 \pm 5 \mathrm{~cm}$ \\
\hline 1 & $(0 \% \mathrm{MP}+0 \% \mathrm{FA})$ & $79 \mathrm{~cm}$ \\
2 & $(15 \% \mathrm{MP}+0 \% \mathrm{FA})$ & $83 \mathrm{~cm}$ \\
3 & $(0 \% \mathrm{MP}+15 \% \mathrm{FA})$ & $80 \mathrm{~cm}$ \\
4 & $(15 \% \mathrm{MP}+15 \% \mathrm{FA})$ & $87 \mathrm{~cm}$ \\
5 & $(0 \% \mathrm{MP}+0 \% \mathrm{FA})$ & $75 \mathrm{~cm}$ \\
6 & $(15 \% \mathrm{MP}+0 \% \mathrm{FA})$ & $81 \mathrm{~cm}$ \\
7 & $(0 \% \mathrm{MP}+15 \% \mathrm{FA})$ & $79 \mathrm{~cm}$ \\
8 & $(15 \% \mathrm{MP}+15 \% \mathrm{FA})$ & $84 \mathrm{~cm}$ \\
\hline
\end{tabular}


Table 4. Compressive strength (MPa)

\begin{tabular}{l|cccc}
\hline Group & Type of Mix & 3 Days & 7 Days & 28 Days \\
\hline 1 & $(0 \% \mathrm{MP}+0 \% \mathrm{FA})$ & 34.55 & 43.45 & 62.63 \\
2 & $(15 \% \mathrm{MP}+0 \% \mathrm{FA})$ & 28.06 & 34.50 & 56.43 \\
3 & $(0 \% \mathrm{MP}+15 \% \mathrm{FA})$ & 25.81 & 34.34 & 56.72 \\
4 & $(15 \% \mathrm{MP}+15 \% \mathrm{FA})$ & 18.56 & 24.66 & 34.29 \\
5 & $(0 \% \mathrm{MP}+0 \% \mathrm{FA})$ & 62.14 & 66.87 & 78.35 \\
6 & $(15 \% \mathrm{MP}+0 \% \mathrm{FA})$ & 54.89 & 56.80 & 69.31 \\
7 & $(0 \% \mathrm{MP}+15 \% \mathrm{FA})$ & 55.92 & 60.30 & 65.47 \\
8 & $(15 \% \mathrm{MP}+15 \% \mathrm{FA})$ & 39.41 & 40.08 & 57.84 \\
\hline
\end{tabular}

Table 5. Results of unit weight $\left(\mathrm{kg} / \mathrm{dm}^{3}\right)$ and water absorbtion $(\%)$

\begin{tabular}{l|ccc}
\hline Sr. No & Type of Mix & Unit weight $\left(\mathrm{kg} / \mathrm{dm}^{3}\right)$ & Water Absorbtion $(\%)$ \\
\hline 1 & $(0 \% \mathrm{MP}+0 \% \mathrm{FA})$ & 2.359 & 1.48 \\
2 & $(15 \% \mathrm{MP}+0 \% \mathrm{FA})$ & 2.338 & 1.68 \\
3 & $(0 \% \mathrm{MP}+15 \% \mathrm{FA})$ & 2.350 & 1.36 \\
4 & $(15 \% \mathrm{MP}+15 \% \mathrm{FA})$ & 2.305 & 1.40 \\
5 & $(0 \% \mathrm{MP}+0 \% \mathrm{FA})$ & 2.340 & 1.50 \\
6 & $(15 \% \mathrm{MP}+0 \% \mathrm{FA})$ & 2.365 & 1.65 \\
7 & $(0 \% \mathrm{MP}+15 \% \mathrm{FA})$ & 2.353 & 1.33 \\
8 & $(15 \% \mathrm{MP}+15 \% \mathrm{FA})$ & 2.336 & 1.38 \\
\hline
\end{tabular}

Table 6. Production cost of $1 \mathrm{~m}^{3} \mathrm{SCC}$ by using material

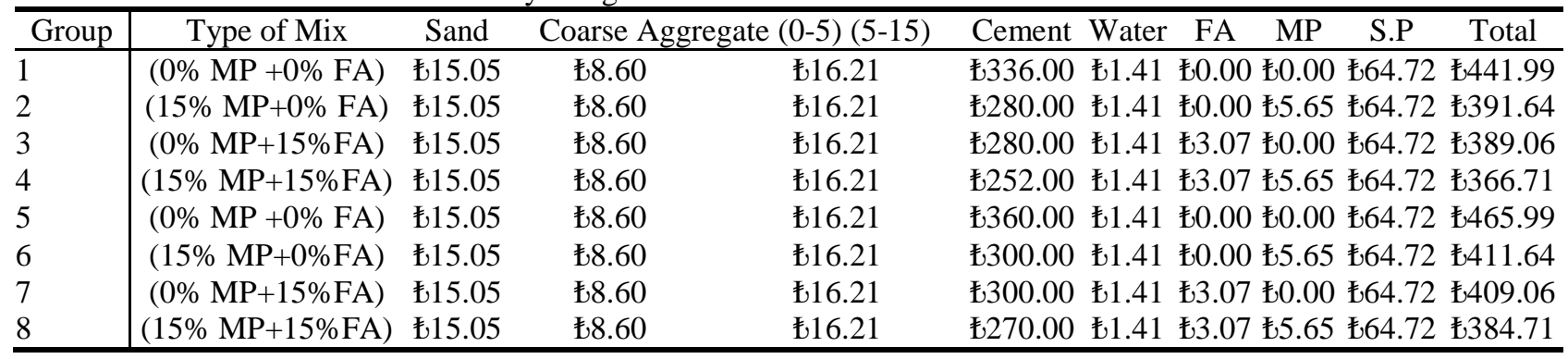

The lowest unit weight values were obtained for OPC 32.5 and 42.5 in groups with $15 \%$ MP and FA additives (groups 4 and 8 ). When the results for water absorption ratios were examined, it was seen that these values decrease in the same groups in inverse proportion with unit weight. In these reductions, it was observed that close results were obtained both in groups where both materials (FA and MP) were used together and in groups where only FA was used high.

As clearly understood from Figure 6, unit weight decreases with increasing FA and MP ratio in the mixture. The effect of cement type is dominant than that of FA and MP. The effect of cement type is around $10 \%$. The reason behind decreasing unit weight is that the fineness of the cement used was thinner than OPC 42.5. It has been found that using up to $6 \% \mathrm{MP}$ or FA in mixtures with lower strength OPC 32.5 does not change the unit weight of the SCC. However, it was also determined that the higher usage of these ratios in SSC produced with high strength OPC 42.5 does not make a significant difference.

When Figure 7 is examined, it is seen that the negative effect of the FA contribution is more effective in OPC 32.5 and the MP effect is less. Similarly, to these results in terms of water absorption ratio (Figure $7 b$ ), the negative effect of OPC 42 was higher than OPC 32.5.

When Table 6 is examined, it is seen that the SCC production cost is maximum $€ 465,99$ and the minimum is $£ 366,71$ depending on the cement type used, FA and MP ratio.
As clearly understood from Figure 8, production cost decreases with increasing FA and MP ratio in the mixture. The effect of cement type is dominant than that of FA and MP, as in unit weight resultes. The effect of cement type is around $5 \%$ for production cost.

When the relationship between the final strength desired and the production cost is examined in the production of SCC's (Figure 9), it is seen that a cost of approximately $390 \mathrm{z}$ is formed for the desired 50-60 MPa strength, and this cost reaches up to $470 €$ for the desired higher strengths.

\section{Conclusion}

The following results were achieved with this study, which should be taken into consideration in agricultural structures and which can be important in terms of choosing the class and type of concrete required in line with the needs both in planning and construction.

- Thanks to SCC that can be used in agricultural buildings, concrete can be produced by pouring concrete with lower water / dust (w / p: 0.,34) and water cement ratio ( $\mathrm{w} / \mathrm{c}$ : 0,16$)$ and desired flowability.

- It is possible to produce concrete with sufficient strength for concretes used in agricultural structures that are generally constructed as single storeys with the contribution of MP and FA. 
- Considering that the concretes are damaged by the water penetrating into the concrete in acidic and cold weather environments, thanks to the low water absorption ratio thanks to the fluidisers used in SCC, a more void-free concrete, which is also an important issue in terms of agricultural structures, can be obtained.

- In terms of cost, it was found that using FA and MP provides advantage in SCC production, but using other MPs and FAs for other purposes may have a negative effect.

- As a result, it was observed that the contribution of fly ash in SCC was more effective than the contribution of waste marble dust and could be used as powder material.

Within the scope of this study, it is thought that the use of industrial wastes in the self-compacting concrete will provide benefits to both nature and the economy, and also the gains in agricultural structures with the use of industrial wastes in the concrete used in agricultural buildings.

\section{References}

Belie ND, Lenehan JJ, Braam CR, Svennerstedt B, Richardson M, Sonck B. 2000. Durability of Building Materials and Components in the Agricultural Environment, Part III: Concrete Structures, J. agric. Engng Res., 76: 3-16. https://doi.org/10.1006/jaer.1999.0520

Belaidi ASE, Azzouz L, Kadri E, Kenai S. 2012. Effect of natural pozzolana and marble powder on the properties of selfcompacting concrete. Construction and Building Materials, 31: 251-257. https://doi.org/10.1016/j.conbuildmat.2011.12. 109

Celik K, Meral C, Gursel AP, Mehta PK, Horvath A, Monteiro PJ. 2015. Mechanical properties, durability, and life-cycle assessment of self-consolidating concrete mixtures made with blended portland cements containing fly ash and limestone powder. Cement and Concrete Composites, 56: 59-72. https://doi.org/10.1016/j. cemconcomp.2014.11.003

Dhiyaneshwaran S, Ramanathan P, Baskar I, Venkatasubramani R. 2013. Study on durability characteristics of self-compacting concrete with fly ash. Jordan journal of civil engineering, 159(3164): 1-12.

Domone PL. 2006a. Mortar tests for material selection and mix design of SCC, Concrete International. 28(4): 39-45.

Domone PL. 2006b. Self-compacting concrete: An analysis of 11 years of case studies. Cement and concrete composites, 28(2): 197-208. https://doi.org/10.1016/j. cemconcomp.2005.10. 003

Domone PL. 2007. A review of the hardened mechanical properties of self-compacting concrete. Cement and concrete composites, 29(1): 1-12. https://doi.org/10. 1016/j. cemconcomp. 2006.07.010

EFNARC, 2002. Specification and guidelines for self-compacting concrete. European Federation of Producers and Applicators of Specialist Products for Structures.

Ekmekyapar T. 1997. Agricultural Construction. Atatürk University Faculty of Agriculture Offset Facility, 151: Erzurum.

Enbaya M, Memiş S, Kaplan G, Yaprak H. 2019. Use of Marble Powder and Fly Ash in Self-Compacting Concrete. ICELIS 2019, 1: 480-484.

Gaywala NR, Raijiwala DB. 2011. Self-compacting concrete: A concrete of next decade. Journal of Engineering Research \& Studies, 2(4).

Habert G, De Lacaillerie JDE, Roussel N. 2011. An environmental evaluation of geopolymer based concrete production: reviewing current research trends. Journal of cleaner production, 19(11): 1229-1238. https://doi.org/ 10.1016 /j.jclepro.2011.03.012
Huntzinger DN, Eatmon TD. 2009. A life-cycle assessment of Portland cement manufacturing: comparing the traditional process with alternative technologies. Journal of Cleaner Production, 17(7): 668-675. doi:10.1016/j.jclepro.2008. 04.007

Karabacak A, Topak R. 2007. Structural Conditions and Problems of Dairy Cattle Barns in Ereğli Vicinity. Selcuk Journal of Agriculture and Food Sciences, 21(42): 55-58.

Karaman S. 2005. Environmental Pollutions Caused by Animal Barns in Tokat Province and Solution Possibilities, GOÜ. Journal of Faculty of Agriculture, 22 (2): 57-65.

Kumanayake R, Luo H, Paulusz N. 2018. Assessment of material related embodied carbon of an office building in Sri Lanka. Energy and Buildings, 166: 250-257. https://doi.org/10.1016/ j.enbuild.2018.01.065

Memiş S, Kaplan G, Yıldızel SA. 2017. Investigation of Usability Potential Geopolimer Concrete at Animal Barns Abstract. Turkish Journal of Agriculture-Food Science and Technology, 5(11): 1365-1370.

Murthy NK, Rao N, Reddy IR, Reddy MVS. 2012. Mix Design procedure for self-compacting concrete. IOSR Journal of Engineering, 2(9): 33-41.

Okamura H, Ouchi M. 2003. Self-compacting concrete. Journal of Advanced Concrete Technology, 1(1):5-15.

Okamura H, Ozawa K. 1995. Mix design for self-compacting concrete. Concrete Library of Japanese Society of Civil Engineers 25(6):107-120.

Okuroğlu M, Delibaş VL. 1986. Suitable Environmental Conditions in Animal Shelters. Livestock Symposium, 5-8.

Ondova M, Stevulova N, Zelenakova E. 2011. Energy savings and environmental benefits of fly ash utilization as partial cement replacement in the process of pavement building. Chemical Engineering Transactions, 25: 297-302.

Ouchi M. 2000. Self-compacting concrete - development, applications and investigations. Nordic Concrete ResearchPublications, 23: 29-34.

Sadrmomtazi A, Dolati-Milehsara S, Lotfi-Omran O, SadeghiNik A. 2016. The combined effects of waste Polyethylene Terephthalate (PET) particles and pozzolanic materials on the properties of self-compacting concrete. Journal of Cleaner Production, 112: 2363-2373. https://doi.org/10.1016/ j.jclepro.2015.09. 107

Shetty MS. 2012." Concrete Technology" (Theory and Practice), S.Chand and Company Limited, New Delhi, Seventh Edition.

Soyer G. 2014. Fertilizer Management Practices in Dairy Cattle Farms in Aydin Province and Development of Fertilizer Usage Opportunities in Crop Production (Master's Thesis), Adnan Menderes University, Institute of Science and Technology, Aydın.

Tayeb B, Abdelbaki B, Madani B, Mohamed L. 2011. Effect of marble powder on the properties of self-compacting sand concrete. The Open Construction and Building Technology Journal, 5(1): 25-29. DOI: 10.2174/ 1874836801105010025

TS EN 772-4, Methods of test for masonry units - Part 4: Determination of real and bulk density and of total and open porosity for natural stone masonry units, TSE, Ankara, 2000.

TS EN 771-1. 2005. Specification for masonry units - Part 1: Clay masonry units, TSE, Ankara.

Usta S. 2011. Free Stall Dairy Cattle Farms Architectural Layout Plan Principles and Suggestions for the Nature of Manufacturer Type Residential Development Plans. SDU Journal of Technical Sciences, 1(2): 29-42.

Wells T, Melchers RE. 2014. An observation-based model for corrosion of concrete sewers under aggressive conditions. Cement and Concrete Research 61: 1-10. https://doi.org/10.1016/j.cemconres.2014.03.013

Zhao H, Sun W, Wu X, Gao B. 2015. The properties of the selfcompacting concrete with fly ash and ground granulated blast furnace slag mineral admixtures. Journal of Cleaner Production, 95: 66-74. https://doi.org/10.1016/j.jclepro. 2015.02.050 